\title{
Impact of forest fire on diversity of hymenopteran insects - a study at Copia species-used forest, Son La Province
}

\author{
Tác động của cháy rùng tới đa dạng nhóm côn trùng cánh màng - nghiên cưu \\ điểm tại khu rùng đặc dụng Copia, tỉnh Son La
}

Research article

Pham Thi Nhi, Hoang Vu Tru \& Pham Van Phu

Institute of Ecology and Biological Resources, Vietnam Academy of Science and Technology, 18 Hoang Quoc Viet, Hanoi, Vietnam

\begin{abstract}
Besides the unsustainable exploitation, farming activities and economic development activities, forest fire is considered as one of the major threats to biodiversity and deforestation in Vietnam. In forest ecosystems, any changes in insect communities can affect species composition, nutrient cycling and numerous other ecological processes. The impact of forest fires, however, is not equal to different insect groups. In this paper, we study the impact of forest fires to hymenopteran insects at Copia species-use forest, Son La Province. This is the first time this kind of study has been taken place in Vietnam.
\end{abstract}

Bên cạnh việc khai thác không bền vũng, tập quán canh tác và các hoạt động phát triển kinh tế, cháy rùng được xem là một trong nhũng mối đe dọa chính ảnh hưởng tiêu cực tới đa dạng sinh học và mất rù̀ng ở Việt Nam. Trong các hệ sinh thái rùng, nhũng thay đổi trong cấu trúc của quần xã côn trùng có ảnh hưởng tới thành phần loài, chu trình dinh duỡng và rất nhiều quá trình sinh thái khác. Tuy nhiên mức độ ảnh hưởng của cháy rùng tới các nhóm côn trùng khác nhau là khác nhau. Trong bài báo này, chúng tôi nghiên cứu tác động của cháy rùng tới nhóm côn trùng cánh màng tại khu rùng đặc dụng Copia, tỉnh Sơn La. Đây cũng là lần đầu tiên tác động của cháy rùng tới nhóm côn trùng cánh màng được thực hiện ở Việt Nam.

Keywords: Hymenoptera, forest fire, diversity, Copia species-use forest

\section{Introduction}

Forest fire is a type of landscape fire, a broad category also comprising fires in steppes, bogs, grasslands and tundras. Fires in forests are usually more disastrous than those in other habitats because of the large volumes of burned plant biomass and the rapid spread of the flames.

In 2010, Vietnam's forests covered 13,258,843 ha (39.1\% of the total land area), of which $10,339,305$ ha were natural forests $(82.7 \%)$ and $2,919,538$ ha forest plantations (17.3\%) (FPD Vietnam, 2010). During the dry season, there are about six million ha of forest with high potential of forest fire risk (about 50\% of Vietnam's total forest area), located in 48 different provinces (Hoang 2007). In the context of climate changes, weather extremes in $\mathrm{Vi}$ etnam are likely to become more severe and abundant, which could significantly increase the frequency of forest fires.

Son La Province is known as a hotspot of forest fire in Vietnam since it experiences long dry period together with hot and dry wind from the West as well as the farming habits of local communities, for instance slash and burn forest for rice and corn fields. According to the Forest Protection Department, a total of 2630 points of forest fires have been recorded in Son La Province since 2010 representing the highest number of forest cases in the country.

Forest fire can affect insects by killing them directly or by altering soil properties, overstory or understory vegetation, tree density, or other aspects of their habitat. Both fire and insects are critical and intrinsic components of forest ecosystems, affecting species composition, nutrient cycling, and numerous other ecological processes. Interactions of 
fire and insects can delay or redirect forest succession and can have significant consequences for forest productivity and biological diversity (McCullough et al. 1998).

Hymenoptera is the third-largest order of insects, comprising the sawflies, wasps, bees, and ants. Not only interesting in great species richness, Hymenoptera insects are attracted by their diverse in life ways. They are phytophagous or entomophagous; parasitoids or predators; solitary or having social life. Due to their diverse behaviors, they live in many kinds of habitat, for example, in the ground, on the plants, on other animals...Despite of their different life ways, adults of most Hymenoptera are sun-loving insects that spend a great deal of time on the wing (Gauld \& Bolton, 1988).
By comparison the species diversity, functional composition, and population abundance of insects at three different habitats: un-burned forest, long-time burned forest and newly burned forest, we intend to assess the impact of forest fire on diversity of hymenopteran insects for the first time from Vietnam based on a case study at Copia speciesused forest in Son La province.

\section{Material and methods}

Material for this study was collected by malaise traps and light traps from 27th April 2016 to 2nd May 2016 at three habitat types at the Copia special-use forest: type 1: Unburned forests, type 2: Newly burned forest (after fire 4-8 weeks), and type 3: Forests burned in 1-3 years.
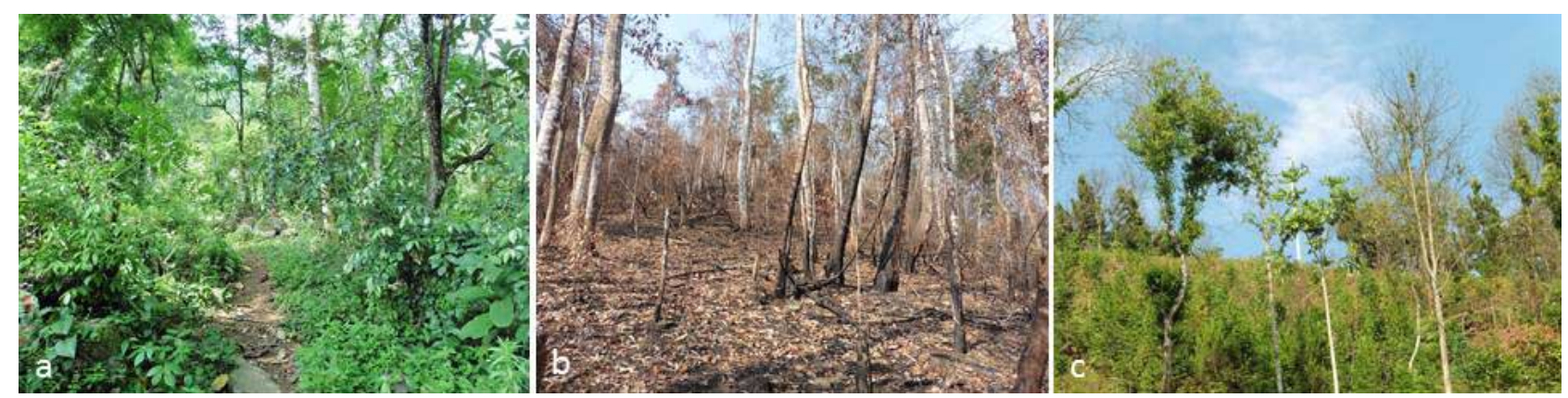

Figure 1. Three habitat types for this study: $a$ - un-burned forest; $b$ - newly burned forest; $c$ - forest burned in 13 years

In the laboratory, the material was sorted and identified to family level was based on Goulet \& Huber (1993) and Borror et al. (1989), to generic and species by a numerous of scientific papers. The data were analyzed statistically by PAST software (Hammer et al., 2001).

Some indexes used in this paper are:

- Similarity index (Sorensen's coefficient): $d_{j k}=2 \mathrm{~A} /$ $(2 \mathrm{~A}+\mathrm{B})$,

Of which A for total species number of the two habitats and $B$ for total number of species with presence in just one habitat.

- Margalef index: $\mathrm{d}=(\mathrm{S}-1) / \log \mathrm{N}$

- Shannon - Weiver index: $H^{\prime}=-\sum(n i / N) \log (n i / N)$

Of which $S$ for total collected species, $N$ for total collected samples (individuals); ni-number of individuals of species $i$.

\section{Results}

\subsection{Hymenopteran insect composition at Co- pia special-use forest}

By using both malaise traps and light traps, a total of 572 specimens of 255 species/species-form in 32 hymenopteran families were collected. Of which representatives of 31 families were collected by malaise traps and four families were recorded by light traps only. Ichneumonidae is the most species-rich family with 106 species (or $41.6 \%$ of total recorded species), followed by Braconidae with 48 species (or 18.8\%). Two families Formicidae and Scelionidae contain 12 species, each, (or 4.7\%). Up to 13 families, in contrast, were represented by only one species.

\subsection{Impacts of forest fire on diversity of hy- menopteran insects}

At the habitat type 3 where forest fires have taken place for 1-3 years, the hymenopteran assemblage was most abundant and species-rich. A total of 230 individuals of 125 hymenopteran species were collected from this habitat type. Species richness was lowest at the habitat type 1 where no forest fires happened during that time period with only 84 recorded and 189 specimens. And at newly burned forests (habitat type 2), 167 specimens of 105 species were recorded. Number of species of each hymenopteran family is shown in table 1 . 


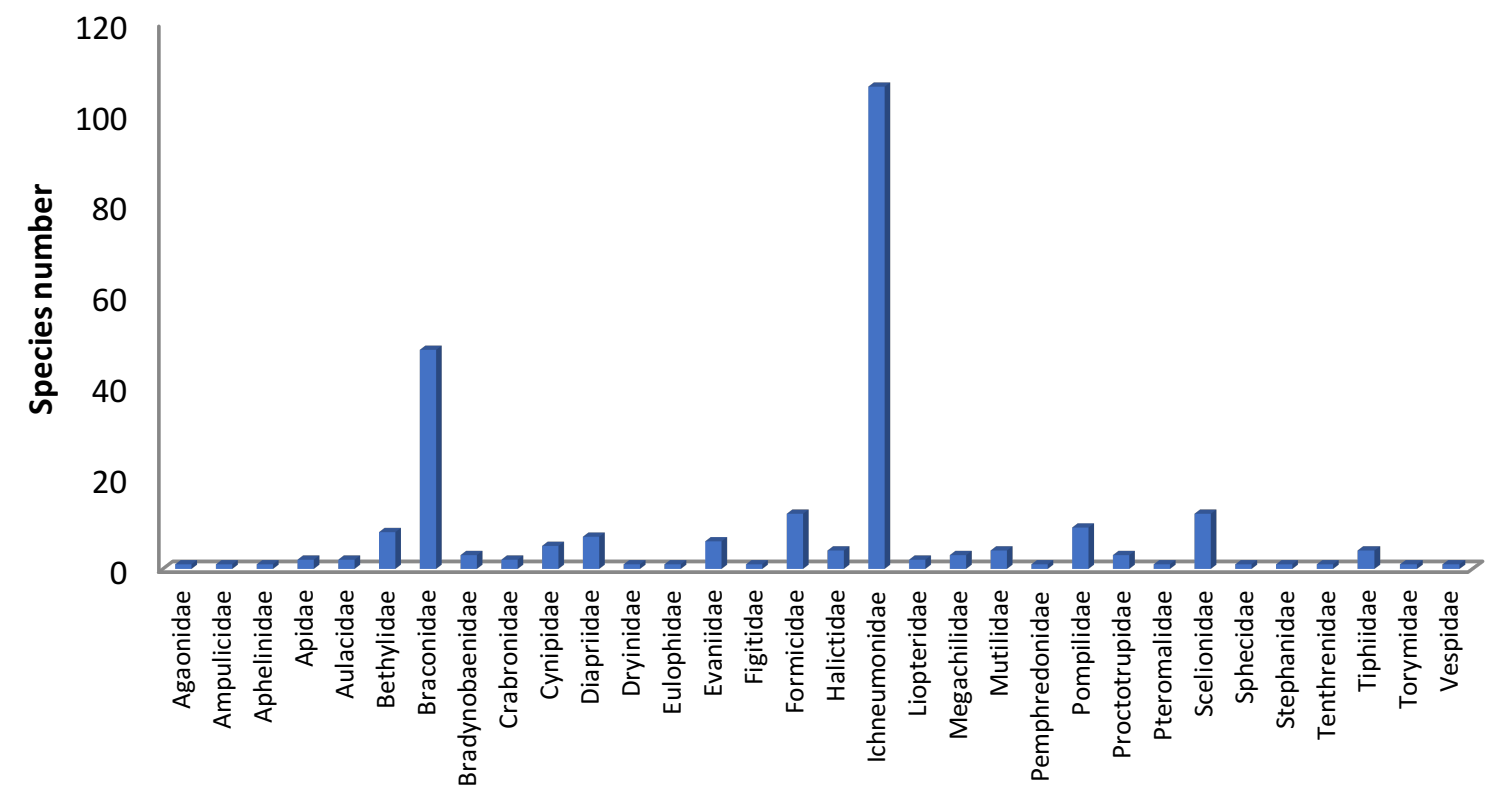

Figure 2. Species composition of hymenopteran insects at Copia special-use forest

Table 1. Number of hymenopteran insects collected at each habitat type

\begin{tabular}{|c|c|c|c|c|}
\hline \multirow{2}{*}{ No } & \multirow{2}{*}{ Family } & \multicolumn{3}{|c|}{ Species number } \\
\hline & & Habitat type 1 & Habitat type 2 & Habitat type 3 \\
\hline 1 & Agaonidae & 0 & 0 & 1 \\
\hline 2 & Ampulicidae & 0 & 1 & 0 \\
\hline 3 & Aphelinidae & 0 & 0 & 1 \\
\hline 4 & Apidae & 1 & 2 & 1 \\
\hline 5 & Aulacidae & 0 & 2 & 0 \\
\hline 6 & Bethylidae & 3 & 3 & 5 \\
\hline 7 & Braconidae & 10 & 18 & 29 \\
\hline 8 & Bradynobaenidae & 2 & 1 & 1 \\
\hline 9 & Crabronidae & 2 & 0 & 0 \\
\hline 10 & Cynipidae & 0 & 0 & 5 \\
\hline 11 & Diapriidae & 2 & 3 & 4 \\
\hline 12 & Dryinidae & 1 & 0 & 0 \\
\hline 13 & Eulophidae & 0 & 0 & 1 \\
\hline 14 & Evaniidae & 3 & 3 & 5 \\
\hline 15 & Figitidae & 1 & 1 & 0 \\
\hline 16 & Formicidae & 1 & 7 & 6 \\
\hline 17 & Halictidae & 1 & 1 & 2 \\
\hline 18 & Ichneumonidae & 41 & 44 & 43 \\
\hline 19 & Liopteridae & 0 & 0 & 2 \\
\hline 20 & Megachilidae & 1 & 1 & 1 \\
\hline 21 & Mutilidae & 3 & 2 & 0 \\
\hline 22 & Pemphredonidae & 0 & 0 & 1 \\
\hline 23 & Pompilidae & 2 & 6 & 7 \\
\hline 24 & Proctotrupidae & 0 & 0 & 3 \\
\hline 25 & Pteromalidae & 0 & 1 & 0 \\
\hline 26 & Scelionidae & 8 & 4 & 4 \\
\hline 27 & Sphecidae & 0 & 0 & 1 \\
\hline 28 & Stephanidae & 0 & 1 & 0 \\
\hline 29 & Tenthrenidae & 0 & 0 & 1 \\
\hline 30 & Tiphiidae & 0 & 4 & 1 \\
\hline 31 & Torymidae & 1 & 0 & 0 \\
\hline 32 & Vespidae & 1 & 0 & 0 \\
\hline & & 84 & 105 & 125 \\
\hline
\end{tabular}

The low Sorensen indexes show that the compositions of hymenopteran insects between the three habitat types were relatively different. Only 10 species were found at all three habitat types. Species composition at habitat type 1 was most similar to that of habitat type $3\left(\mathrm{~d}_{\mathrm{jk}}=0.27\right)$ and most different to that of habitat type $2\left(\mathrm{~d}_{\mathrm{jk}}=0.18\right)$ with 28 and 
17 co-occurring species, respectively. The similarity on the species composition between the habitat type 2 and habitat type 3 was 0.21 with 24 species were co-occurred. There were 49 species found currently only from habitat type 1 , and from habitat $2 \& 3$ were 74 and 83 species, respectively. In figure 2 , the species composition of habitat type 2 formed a separate clade with those of habitat type $1 \& 3$ with the strong support (Bootstrap value $=100$ ).

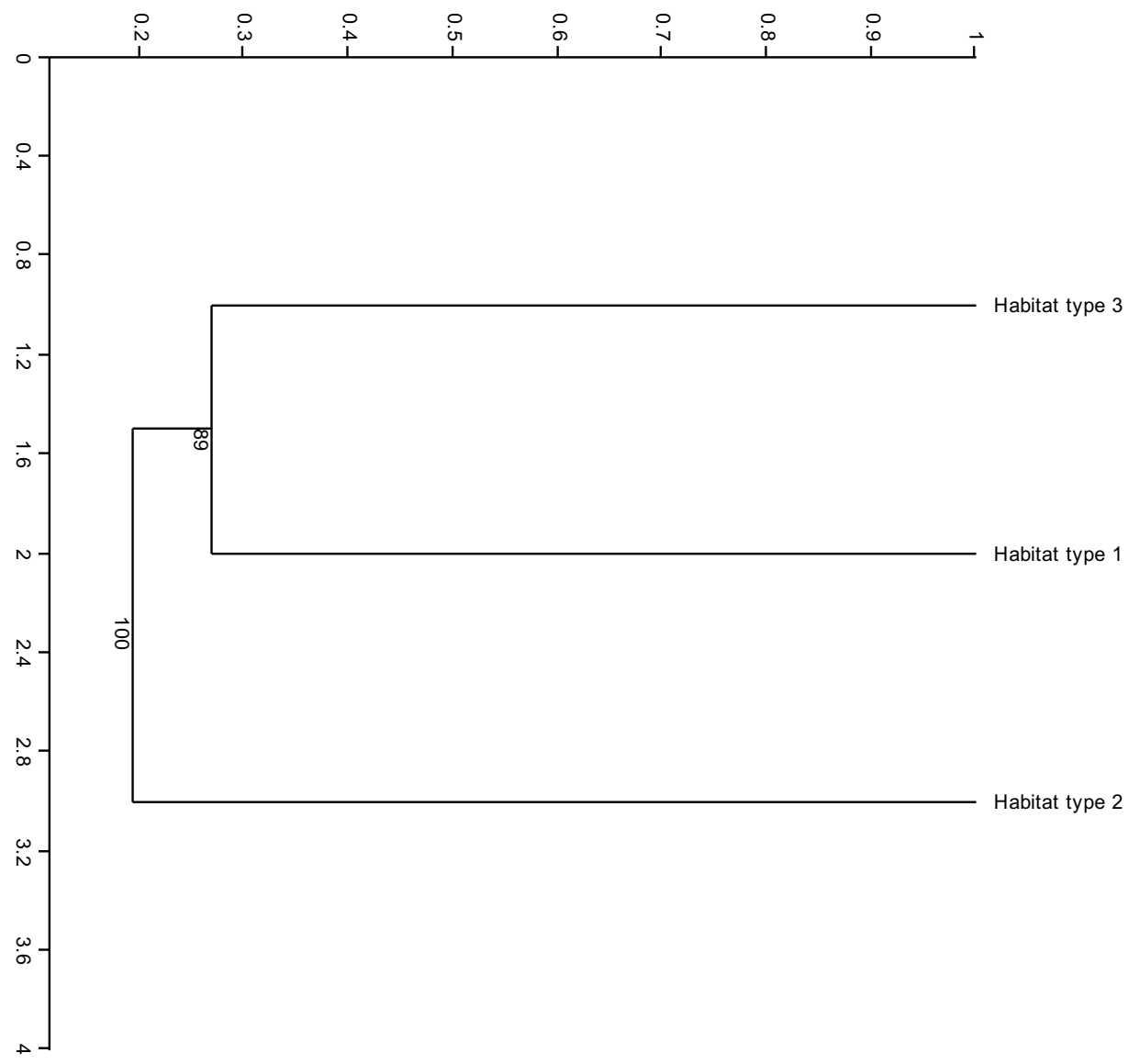

Figure 3. The similarity in species composition of hymenopteran insects among habitat types (Bootstrap value: 1000)

The two diversity indexes including Shannon - Weiver and Margalef show that the hymenopteran insects at the newly burned forests (habitat type 2) less diversed than hymenopteran assemblage at the habitat type 3 but more diversed than habitat type 1 where no forest fires happened in the past. The Shannon - Weiver indexes at three habitat type 1, 2, 3 were 3.854, 4.281 and 4.479 and the Margalef indexes were $15.83,20.23$ and 22.8 , respectively.

\section{Discussion}

The species richness and abundance of hymenopteran insects were highest in the forests where burned happened in recent 1-3 years. In comparison between the unburned forests and freshly forests, it is amazing that the species number of hymenopteran insects were higher in the forests where burned happened in 4-8 weeks. It is believable that some insects are 'fire-adapted' in some ways and also the fires seemly provide more bare ground for ground-nesting bees and others to exploit. Similar trends were observed in Mediterranean forest ecosystems where hymenopteran insects and moths were attracted by fires and new habitats created after fires (Elia et al., 2011). Besides their preference activities to forest gaps several characteristics of burned areas can favour insects, e.g. an increased amount of dead wood and breeding material, reduced competition, more easily attainable nutrients and changed microclimate, e.g. decreased humidity and increased sun radiation (Hjältén et al. 2006). In the forests where burned happened between 1-3 years, the habitats are in restoration processes seemly most suitable for hymenopteran insects. Therefore post-fire management plans related to vegetation cover can indirectly affect the composition of insects at Copia special-use forest.

Although the diversity indexes were lowest at the habitat where no forest fires happened in the past, the low values of Sorensen indexes clearly showed that forest fire affected remarkably the species composition of hymenopteran assemblages at three habitat types in Copia special-use forest. The hymenopteran assemblage at the newly burned forest was quite different with assemblages of the two other habitats. However, our data resulted from a single survey, the impacts of forest fires in the change of the species composition of hymenopteran insects need to be verified by further studies.

\section{Acknowledgements}

This research is funded by Institute of Ecology and Biological Resources (Project number: IEBR.DT.07/16-17) and by the Vietnamese Ministry of Education and Training 
(Grant number: B2016-TTB-01). We thanks Assoc. Prof. Dr Khuat Dang Long, Dr. Nguyen Thi Phuong Lien, MSc. Dang Van An, MSc. Pham Huy Phong and BSc. Nguyen Dac Dai (IEBR, Vietnam) and Yoto Komeda (Kyushu University, Japan) for their supports in identification process.

\section{References}

[1] Borror, D.J., Triplehorn, C.A. \& Johnson, N.F., 1989. An Introduction to the study of insects. Sixth edition. Saunders College Publishing. 875 pp.

[2] Elia, M., Lafortezza, R., Tarasco, E., Colangelo, G., \& Sanesi, G., 2011. Influence of forest fires on insect diversity: a case study in Apulia. Forest@, 8(1): 1321.

[3] Elia, M., Lafortezza, R., Tarasco, E., Colangelo, G., \& Sanesi, G., 2012. The spatial and temporal effects of fire on insect abundance in Mediterranean forest ecosystems. Forest Ecology and Management, 263: 262-267.

[4] Gauld, I. \& Bolton, B., 1988. The Hymenoptera. Oxford University Press. 344 pp.

[5] Goulet, H. \& Huber, J.T., 1993. Hymenoptera of the world: An identification guide to families. Agriculture Canada Research Branch, Monograph No. 1894E. 668 pp.

[6] Hammer, Ø., Harper, D.A.T. \& Ryan, P.D., 2001. PAST: Paleontological statistics software package for education and data analysis. Palaeontologia Electronica 4(1): 9pp

[7] Hjältén, J., Atlegrim, O., Sandström, F., Pettersson, R. \& Rexstad, E. A., (2006. Occurrence of flat bugs (Heteroptera: Aradidae) in burned and unburned forests. Entomologica Fennica, 17: 130-135.

[8] Hoang, M. (2007). Status of Forest Fire Management and Control in Vietnam, http://www.restec.or.jp/geoss_ap $1 /$ materi-

als/PDF/ForestFire/2day/2day_8_Hien.pdf (Last access 08/08/2016)

[9] Forest Protection Department of Vietnam, 2010. Applying IT and Remote Sensing Technology for Forest Fire Management in Vietnam.

[10] McCullough, D., Werner, R., \& Neumann, D., 1998. Fire and insects in northern and boreal forest ecosystems of North America. Annual Review of Entomology, 34: 107-127. 